\title{
PERTIMBANGAN PENGARUH BEBAN DALAM PERANCANGAN PEMBANGKITAN SISTEM TENAGA LISTRIK
}

\author{
Irman Amri \\ Dosen Fakultas Teknik Universitas Al-Amin Muhammadiyah Sorong
}

\begin{abstract}
Abstrak
Perencanaan pembangkit selalu harus mempertimbangkan beban khususnya pembagian optimal beban, perhitungan rugi ketika beban dilayani serta pengaruh perubahannya terhadap perubahan frekwensi, agar pembangkitan dapat berfungsi optimal ditengah kritisnya sumber daya energi saat ini. Kasus 1 menunjukkan bahwa besar beban seharusnya yang mampu ditanggung adalah $42 \mathrm{MW}$ namun untuk suplai beban yang letaknya cukup jauh beban yang mampu untuk disuplai adalah 35, 459 MW. Untuk kasus 2 pembagian beban pada kondisi awal pukul 18.00 PLTG,PLTA dan PLT Tello masing-masing sebesar 50 MW dan PLTD sebesar 15 MW dengan penambahan beban $20 \mathrm{MW}$ menyebabkan terjadi penurunan frekwensi sistem menjadi 49,89 sedangkan daya yang akan ditanggung akan terbagi PLTG Sengkang 54,04 MW, PLTA Bakaru 56,06 MW, PLT Tello 53,7875 MW dan PLTD Suppa 21,06 MW. Dengan demikian governor akan kembali bereaksi untuk mengembalikan kondisi kepada keadaan semula.
\end{abstract}

Kata Kunci : Pembangkit, Beban, Frekuensi.

\section{PENDAhUluAN}

\subsection{Latar Belakang}

Energi listrik merupakan salah satu bentuk energy yang bermanfaat dalam kehidupan manusia dan merupakan salah satu faktor yang penting dalam menunjang pembangunan suatu daerah. Seiring dengan pertambahan penduduk yang diiringi dengan pertumbuhan ekonomi dan perkembangan sector industri menyebabkan kebutuhan akan energi listrik semakin besar. Hal ini terjadi di kota-kota besar maupun di daerah pedesaan, sehingga perlu adanya suatu penyediaan dan penyaluran tenaga listrik secara optimal baik dari segi kualitas maupun kuantitas Meningkatnya permintaan akan energi listrik menyebabkan kemampuan dari jarinngan maupun pembangkitan yang cukup.

Pembangkitan merupakan sebuah proses produksi tenaga listrik, dilakukan dalam pusat-pusat tenaga listrik atau sentralsentral, dengan menggunakan generatorgenerator dengan berbagai jenis penggeraknya . Transmisi atau penghantaran adalah memindahkan tenaga listrik ini dari pusat-pusat tenaga listrik secara besarbesaran ke tempat-tempat tertentu, yang dikenal dengan gardu induk. Dari gardu gardu induk ini tenaga listrik didistribusikan ke gardu-gardu distribusi, kemudian ke para pelanggan atau konsumen. Fasilitas-fasilitas pembangkitan dan transmisi biasanya kaitmengait secara ekonomis, dalam pilihan lokasi, desain dan hubungan ekonomi skala. Sering terjadi, bahwa penugasan organisasi dari pembangkitan dan transmisi dilakukan bersamaan, sedangkan distribusi sering diusahakan sendiri.

Saat ini energi listrik semakin besar peranannya, dimana kebutuhan akan energi listrik tersebut telah menjadi komoditi yang mempengaruhi hidup orang banyak, hal ini terlihat dari ketergantungan pemakaian energi listrik, baik pada sektor domestik maupun pada sektor industri. Untuk tetap dapat melayani beban maka keseluruhan dari sistem kelistrikan haruslah dikembangkan mengikuti perkembangan kebutuhan.

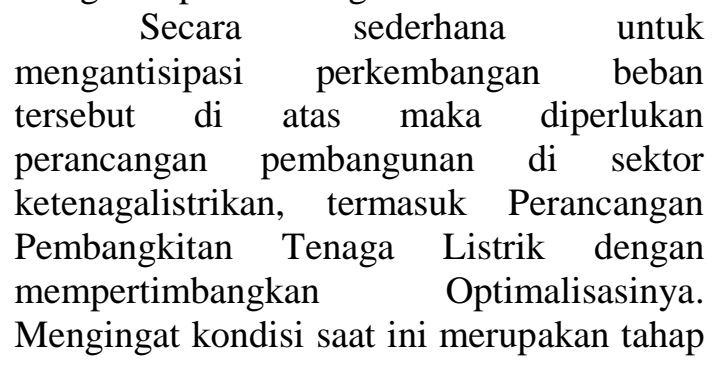


kritis dalam pembangunan sektor ketenagalistrikan.

\subsection{Rumusan Masalah}

Perancangan Pembangkitan system Tenaga Listrik, harus mempertimbangkan kondisi optimal ketika system tenaga tersebut bekerja, oleh karena itu ada beberapa permasalahan yang harus diketahui berhubungan dengan perancangan pembangkit tersebut, antara lain :

1. Bagaimanakah Perhitungan pembagian beban yang harus dilakukan ketika beberapa generator bekerja bersama sekaligus?

2. Bagaimanakah perhitungan Nilai Rugi rugi dalam sebuah transmisi ketika Pembangkit melayani beban $?$

3. Bagaimanakah perhitungan perubahan frekwensi ketika terjadi perubahan beban?

\subsection{Tujuan}

Tujuan penulisan ini adalah :

1. Untuk mengetahui besar pembagian beban yang berlaku jika generator bekerja bersama sama menyuplai daya serta ketika daya tiba tiba bertambah atau berkurang .

2. Untuk mengetahui besar Nilai Rugi rugi dalam sebuah transmisi ketika Pembangkit melayani beban.

3. Untuk mengatahui nilai perubahan frekwensi ketika terjadi perubahan beban .

\section{LANDASAN TEORI}

\subsection{Perhitungan Model Operasi Optimal}

\section{Model Pembangkit Listrik Tenaga Thermal}

Pada pembahasan ini diambil $\mathrm{m}$ buah pembangkit termal yang beroperasi pada suatu bus yang sama, seperti diperlihatkan pada gambar berikut

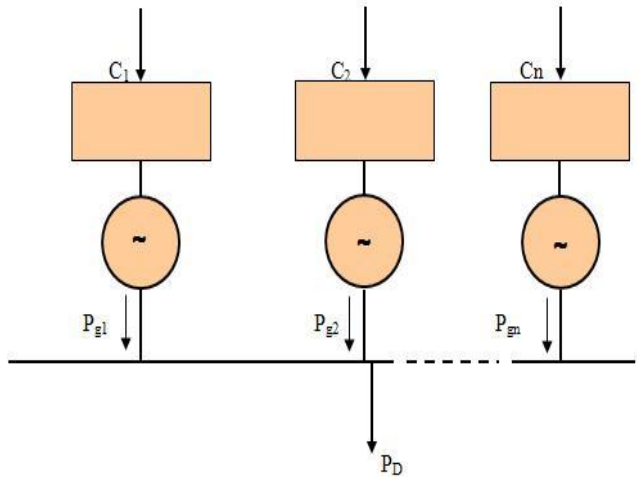

Gambar 1. m buah pembangkit thermal beroperasi pada satu bus yang sama

Pembangkit tersebut mempunyai biaya bahan yang berbeda yaitu (Fi) dengan daya aktif (Pi) yang dimodelkan dengan persamaan polynomial kuadrat, biaya bahan bakar total dari "plant" adalah merupakan penjumlahan setiap unit pembangkit dengan satuan \$/jam.

$$
F=\sum_{\lambda=1}^{m} \alpha_{i}+\beta_{i} P_{i}+\delta_{i} P_{i}^{2}
$$

dimana: $\alpha_{i}, \quad \beta_{i} \quad \operatorname{dan}_{i}$ adalah suatu konstanta.

Dalam menentukan biaya minimum (F), maka persamaan (1) di deffrensial terhadap (Pi) dan disamakan dengan nol.

$$
\frac{d F}{d P i}=0, \text { dengan }(i=1 \quad . m)
$$

Nilai optimal untuk daya yang dibangkitkan dapat dituliskan dengan persamaan sebagai berikut:

$$
{ }^{P i} \sum=\frac{-\beta_{i}}{2 \delta_{i}}
$$

Daya aktif optimal dan biaya minimal, kalau differensial derajat dua dari $(\mathrm{F})$ terhadap Pi nilainya positif. Kondisi ini dapat diperoleh apabila nilai: $\delta_{i}>0$

Pada persamaan (3) dapat diperoleh daya yang dibangkitkan negatif apabila $\beta_{i}$ dan $\alpha_{i}$ adalah positif nilainya untuk suatu pendefferensialan parsial dilakukan dua kali. Masalah optimisasi untuk memperoleh biaya minimum maka kendalanya harus daya dalam keadaan seimbang, apabila rugi-rugi transmisi diabaikan fungsi kendala dapat dituliskan sebagai berikut: 


$$
P_{D}=\sum_{\lambda=1}^{m}\left(P_{i}\right)
$$

Jika tidak ada fungsi kendala, maka persamaan (3) merupakan suatu penjumlahan seperti berikut:

$$
\sum_{\lambda=1}^{m}\left(P_{i \sum}\right)=-\frac{1}{2} \sum_{\lambda=1}^{m} \frac{\beta_{i}}{\delta_{i}}
$$

Dalam metode lagrange fungsi kendala dapat dituliskan:

$$
\boldsymbol{P}_{D}=\sum_{\lambda=1}^{m}\left(\boldsymbol{P}_{i}\right)=0
$$

Kalau metode lagrange $(\lambda)$ ditarafkan fungsi daya, maka diperoleh rumus:

$$
F=F_{T}+\lambda\left[P_{D}-\sum_{\lambda=1}^{m}\left(F_{i}\right)\right]
$$

Kalau persamaan di atas didefferensialkan ke $\left(\mathrm{P}_{\mathrm{i}}\right)$, diperoleh:

$$
\frac{d F}{d P i}-\lambda=0
$$

Perlu dicatat bahwa jika semua pembangkit independent $\mathrm{t}$, dengan menggunakan metode pengali Lagrange diperoleh nilai $\lambda$ yang sama yaitu:

$$
\lambda=\frac{\alpha F_{1}}{\alpha P_{1}}=\frac{\alpha F_{2}}{\alpha P_{2}}
$$

Selanjutnya $\lambda$ yang merupakan pertambahan biaya dalam analisis optimisasi daya bahan bakar pada suatu system pembangkit energi listrik. Grafik pertambahan biaya pembangkitan seperti pada gambar 4 pada kondisi optimal dari persamaan (11) dapat dirumuskan menjadi:

$$
\beta_{i}+2 \delta_{2} P_{i}-\lambda=0
$$

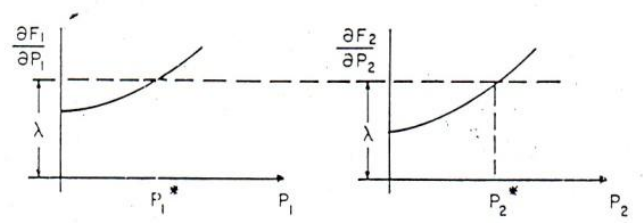

Gambar 2. Ilustrasi pertumbuhan biaya atau pertambahan pembebanan

Selanjutnya nilai dapat ditentukan dengan memperoleh persamaan yang diturunkan diperoleh:

$$
\lambda=\frac{2 P_{D}+\sum_{\lambda=1}^{m}\left(\frac{\beta_{i}}{\alpha_{i}}\right)}{\sum_{\lambda=1}^{m} \delta_{i}-1}
$$

Pada akhirnya dalam pembangkitan optimal dengan penurunan diperoleh persamaan seperti:

$$
P_{i}=\frac{\lambda-\beta_{i}}{2 \delta_{i}}
$$

\subsection{Perhitungan Rugi-rugi Transmisi}

Masalah operasi optimal telah diatas dimana keseimbangan daya dengan rugi transmisi diabaikan. Pada bagian ini untuk operasi ekonomis sistem tenaga listrik ditinjau rugi-rugi transmisi, ambil satu sistem seperti pada gambar (6), sistem radial dengan satu pembangkit.

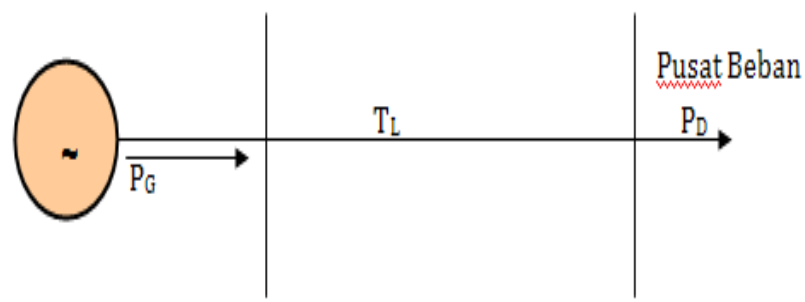

Gambar 3. Sistem transmisi radial

Mencari rugi daya $P_{1}$ dengan daya yng dipasok oleh pembangkit $\mathrm{P}_{\mathrm{G}}$ ke pusat $\mathrm{P}_{\mathrm{D}}$. Diagram ekivalen dari sistem di atas adalah seperti pada gambar 7 .

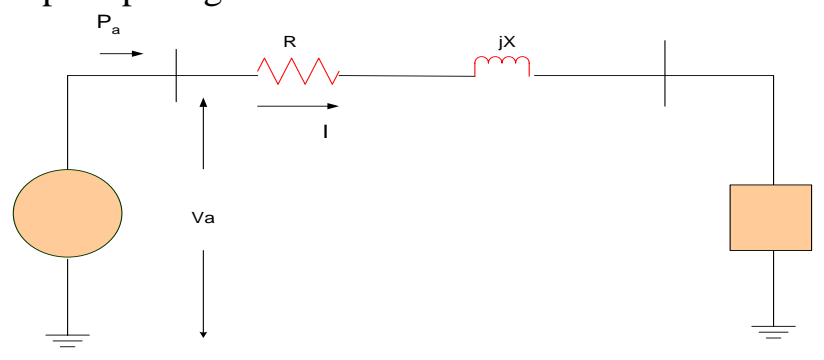

Gambar 4. Rangkaian ekivalent sistem radial

Pada gambar diperoleh rugi-rugi transmisi:

$$
P_{L}=3|I|^{2} \quad R
$$


dimana $\mathrm{R}$ adalah tahanan dari saluran dalam Ohm/phasa. Arus $|I|$ dapat diperoleh dari :

$$
|I|=\frac{P_{a}}{\left(\sqrt{3} \quad\left|V_{a}\right|\right) \cos \varphi_{a}}
$$

$\mathrm{P}_{\mathrm{a}} \quad=$ daya yang dibangkitkan oleh generator

$\mathrm{V}_{\mathrm{a}} \quad=$ tegangan line to line (phasa ke phasa)

$\cos \varphi_{a}=$ factor daya generator

Dengan asumsi ke dua persamaan di atas diperoleh :

$$
P_{L}=\frac{R}{\left|V_{a}\right|^{2} \cos ^{2} \varphi_{a}} P_{a}^{2}
$$

Asumsikan bahwa tegangan generator $V a$ dan $\cos \varphi_{a}$ konstan maka diperoleh:

$$
P_{L}=B P_{a}^{2}
$$

$$
\text { dimana: } B=\frac{R}{\left|V_{a}\right|^{2} \cos ^{2} \varphi_{a}}
$$

Kalau ditinjau dari dua sumber pemasok daya ke pusat beban seperti pada gambar 5 .

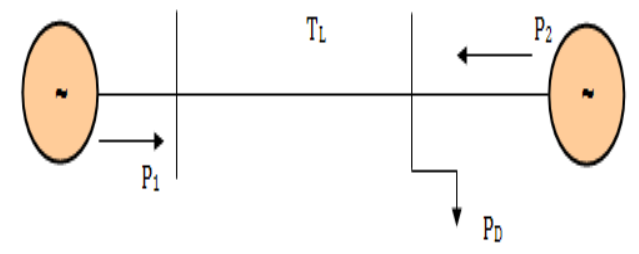

a. Model radial

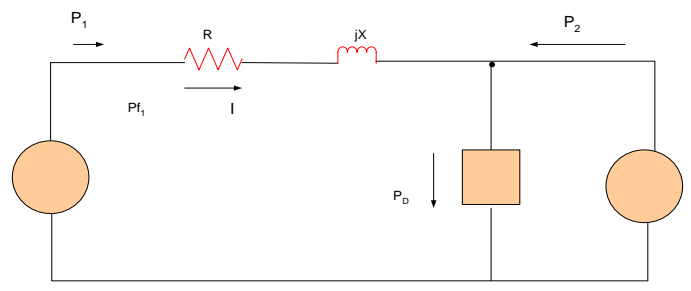

b.Rangkaian Penggantinya

Gambar 5. Sistem radial dengan dua sumber pemasok pada demand $\mathrm{P}_{\mathrm{D}}$

Berdasarkan pada persamaan (15) maka rugi daya dapat diperoleh:

$$
\begin{aligned}
\boldsymbol{P}_{\boldsymbol{L}} & =\boldsymbol{B}_{11} \boldsymbol{P}_{1}^{2} \\
\operatorname{dimana}: \boldsymbol{B}_{11} & =\frac{R}{\left|V_{1}\right|^{2}(P f)^{2}}
\end{aligned}
$$

$$
\begin{aligned}
& \mathrm{V}_{1}=\text { tegangan bus generator } \mathrm{P}_{1} \\
& \mathrm{pf}_{1}=\text { faktor daya pada bus } 1
\end{aligned}
$$

Tinjau dua sumber pemasok daya pada pusat beban seperti pada gambar

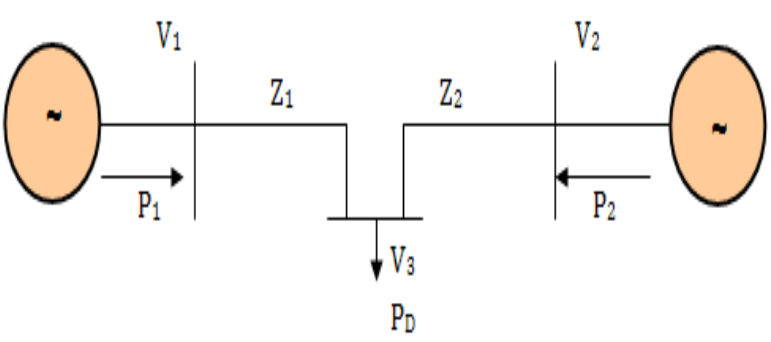

\section{Gambar 6. Dua saluran radial yang} terhubung ke beban

Dua pembangkit terhubung ke bus pusat beban dengan tahanan masing-masing $R_{1 D}$ dan $R_{2 D}$ sehingga rugi daya adalah :

$$
\begin{gathered}
P_{L}=3\left|I_{1}\right|^{2} R_{1 D}+3\left|I_{2}\right|^{2} R_{2 D} \\
= \\
\frac{R_{1 D}}{\left(V_{1}\right)^{2}\left(p f_{1}\right)^{2}}\left(P_{1}\right)^{2}+\frac{R_{2 D}}{\left(V_{2}\right)^{2}\left(p f_{1}\right)^{2}}\left(P_{2}\right)^{2} \\
\boldsymbol{P}_{\boldsymbol{L}}=\boldsymbol{B}_{11} \boldsymbol{P}_{1}^{2}
\end{gathered}
$$

Selanjutnya ditinjau sistem radial dengan tiga saluran seperti pada gambar 7 .

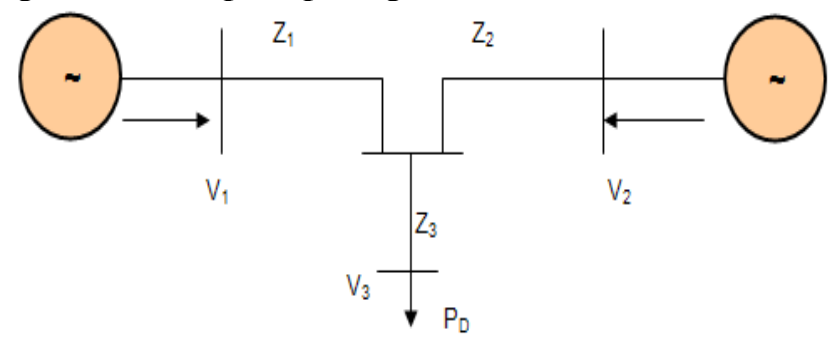

Gambar 7. Sistem pemasok daya dua sumber dengan tiga saluran

Pada gambar 10 tiga saluran dua sumber pemasok daya yaitu $\mathrm{P}_{1}$ dan $\mathrm{P}_{2}$ untuk memenuhi permintaan $\mathrm{P}_{\mathrm{D}}$. Pada saluran bus 
ISSN 1979-7540

beban $\mathrm{P}_{\mathrm{D}}$ ada turunan $\mathrm{R}_{3 \mathrm{D}}$, sehingga diperoleh rugi saluran transmisi.

$P_{L}=B_{11} P_{1}^{2}+2 B_{12} P_{1} P_{2}+B_{22} P_{2}^{2}$.

Besar arus dapat ditentukan dengan harga mutlak.

$$
\begin{aligned}
\left|I_{1}\right| & =\frac{P_{1}}{\sqrt{3}\left|V_{1}\right|\left(p f_{1}\right)} \\
\left|I_{2}\right| & =\frac{P_{2}}{\sqrt{3}\left|V_{2}\right|\left(p f_{2}\right)} \\
\left|I_{3}\right| & =\frac{P_{3}}{\sqrt{3}\left|V_{3}\right|\left(p f_{3}\right)}
\end{aligned}
$$

Sekarang kalau diambil :

$$
P_{D} \cong P_{1}+P_{2}
$$

Diperoleh :

$$
\left|I_{3}\right|=\frac{P_{2}+P_{2}}{\sqrt{3}\left|V_{3}\right|\left(p f_{3}\right)}
$$

kemudian disubsitusikan ke dalam persamaan (18), diperoleh:

$$
\begin{gathered}
P_{L}=\frac{R_{1 D}}{\left|V_{1}\right|^{2}\left(p f_{1}\right)^{2}}\left(P_{1}^{2}\right)+ \\
\frac{R_{2 D}}{\left|V_{3}\right|^{2}\left(p f_{2}\right)^{2}}\left(P_{2}\right)^{2}+\frac{R_{3 D}}{\left|V_{3}\right|^{2}\left(p f_{3}\right)^{3}}\left(P_{1}+P_{1}\right)^{2}
\end{gathered}
$$

Dengan demikian besar konstanta B dapat ditentukan, yaitu:

$$
B_{11}=\frac{R_{1 D}}{\left|V_{1}\right|^{2}\left(p f_{1}\right)^{2}}+\frac{R_{3 D}}{\left|V_{3}\right|^{2}\left(p f_{3}\right)^{2}}
$$

$$
B_{22}=\frac{R_{2 D}}{\left|V_{2}\right|^{2}\left(p f_{2}\right)^{2}}+\frac{R_{3 D}}{\left|V_{3}\right|^{2}\left(p f_{3}\right)^{2}}
$$

$$
B_{12}=\frac{R_{3 D}}{\left|V_{3}\right|^{2}\left(p f_{3}\right)^{2}}
$$

\section{METODOLOGI}

\section{a. Jenis Penelitian}

Jenis penelitian yang dilakukan adalah studi kasus dengan membuat contoh persoalan yang berhubungan dengan pembangkitan dan penyalurannya untuk mengatahui permasalhan permasalahan yang ingin diketahui sesuai tujuan. Data yang digunakan adalah data asumsi dengan tetap mempertimbangkan kondisi nyata dilapangan. Dengan penyederhanaan kondisi. Kondisi ini membawa peneliti untuk menyederhanakan keadaan alamiah (Sembiring, 1995).

\section{b. Teknik Analisis Data}

Analisis data yang digunakan adalah adalah metode studi pustaka/studi literatur, dimana penelitian yang dilakukan melalui penelaah kepustakaan (tinjauan pustaka) yang menyangkut teori-teori yang berhubungan dengan masalah pokok yang dibahas.

Analisis dilakukan untuk 2 contoh kasus yang berbeda yaitu

1. Penentuan besar beban yang harus ditanggung oleh generator yang bekerja serta rugi daya penyaluran

2. Penentuan besar pembagian beban yang optimal untuk generator yang bekerja bersama sama menyuplai beban dengan daya tertentu serta perubahan frekwensinya masing masing jika beban berubah.

Kedua kasus ini masing masing diselesaikan untuk memenuhi tujuan yang ingin dikatahui:

\section{Kasus I. Langkah análisis Datanya :}

1. Memastikan semua data yang diperlukan seperti data Impedasi , Faktor daya serta total daya yang dimiliki telah ada dan diketahui.

2. Menentukan sistem jaringan (panjang/menengah atau pendek)

3. Menghitung rugi rugi daya yang terjadi pada saluran

4. Daya pada beban yang dicari $\left(\mathrm{P}_{\mathrm{D}}\right)$ bisa diketahui.

\section{Kasus 2. Langkah análisis Datanya :}

Selanjutnya dilakukan perhitungan perubahan frekuensi sistem akibat penambahan daya beban pada beban puncak, dengan tahapan-tahapan sebagai berikut:

1. Menentukan kondisi awal, yaitu mengalokasikan daya yang dibangkitkan oleh masing-masing pembangkit. 
ISSN 1979-7540

2. Menghitung nilai konstanta penurunan frekuensi Kf dari masing-masing pembangkit akibat penambahan daya beban.

3. Menghitung konstanta penurunan frekuensi Kf dari keseluruhan sistem

4. Menhitung besarnya penurunan frekuensi system saat terjadi penambahan beban.

5. Menghitung besarnya penambahan daya yang harus disuplai oleh masingmasing pembangkit akibat penambahan beban untuk pengembalian frekuensi pada kondisi semula.

6. Menganalisis pengaruh besar kecilnya speed drop pada masing-masing pembangkit akibat penambahan daya beban.

Kedua kasus diatas setelah dihitung sesuai teknik analisisnya masing masing kemudian disusun menjadi laporan penelitian dan selanjutnya dibuat kesimpulan.

\section{HASIL DAN PEMBAHASAN}

4.1. Kasus I

Suatu sistem tenaga listrik dengan data-data sebagai berikut :

\begin{tabular}{|c|c|c|}
\hline $\begin{array}{ll}\text { PLTG } & \\
\text { Daya } & 20 \\
\text { MW } & \\
\end{array}$ & $\begin{array}{ll}\text { PLTU } & \\
\text { Daya } & 12 \\
\text { MW } & \\
\end{array}$ & $\begin{array}{ll}\text { PLTD } & \\
\text { Daya } & 10 \\
\text { MW } & \\
\end{array}$ \\
\hline $\begin{array}{l}\operatorname{Cos} \varphi= \\
0,81 \\
\mathrm{R}_{\mathrm{Dl}}=0,002 \\
\text { Tegangan }= \\
1 \text { pu }\end{array}$ & $\begin{array}{l}\text { Cos } \varphi= \\
0,80 \\
\mathrm{R}_{\mathrm{D} 2}=0,003 \\
\text { Tegangan } \\
=0,99\end{array}$ & $\begin{array}{l}\operatorname{Cos} \varphi= \\
0,80 \\
\mathrm{R}_{\mathrm{D} 3}=0,001 \\
\text { Tegangan }= \\
0,98 \mathrm{pu}\end{array}$ \\
\hline
\end{tabular}

Dihubungkan / bekerja / beroperasi dalam sistem interkoneksi maka :

a. Tentukan besar beban

b. Tentukan besar rugi daya sistem transmisi panjang

Beban $\mathrm{P}_{\mathrm{D}}$ : $\mathrm{R}_{\mathrm{D} 4}=0,004 ; \operatorname{Cos} \varphi=0,80$ ; Tegangan $=0,995 \mathrm{pu}$

\section{Penyelesaian :}

a. Besar beban yang dilayani oleh ketiga pembangkit PLT tersebut dapat digambarkan sebagai berikut :

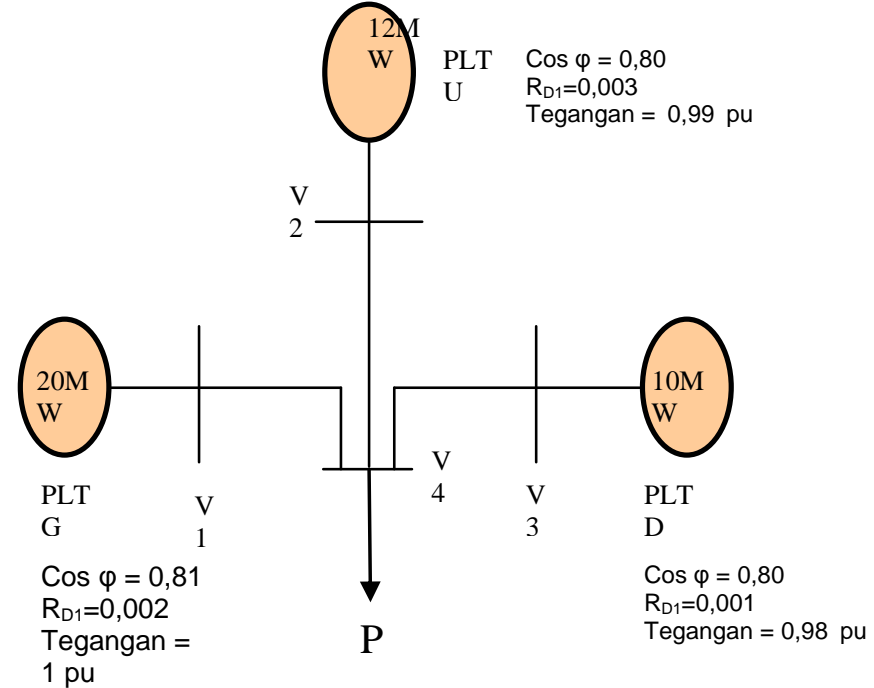

Gambar 8. Sistem tenaga listrik dengan 3 pembangkit

Besar beban yang dapat dilayani oleh ketiga pembangkit tersebut, dengan asumsi bahwa sistem jaringan transmisi pendek dan ada rugi-rugi daya diabaikan sehingga dengan persamaan di bawah ini diperoleh besar beban sebesar :

$$
\begin{aligned}
\mathrm{P}_{\mathrm{G}} & =\sum_{i=1}^{n} P_{g i}=P_{D} \\
P_{D} & =P_{g 1}+P_{g 2}+P_{g 3} \\
P_{D} & =20 \mathrm{MW}+12 \mathrm{MW}+10 \mathrm{MW}=42 \mathrm{MW}
\end{aligned}
$$

Besar beban yang dapat dilayani oleh ketiga pembangkit tersebut jika rugirugi daya saluran transmisi pendek diperhitungkan dengan persamaan berikut :

$$
P_{D}=\sum_{i=1}^{n} P_{g i}-P_{L}
$$

Dimana :

$$
\begin{aligned}
& P_{L}=3\left|I_{1}\right|^{2} R_{D 1}+3\left|I_{2}\right|^{2} R_{D 2}+3\left|I_{3}\right|^{2} R_{D 3} \\
& P_{L}=\frac{R_{D 1}}{\left|V_{1}\right|^{2}\left(p f_{1}\right)^{2}}\left(P_{1}^{2}\right)+\frac{R_{D 2}}{\left|V_{3}\right|^{2}\left(p f_{2}\right)^{2}}\left(P_{2}\right)^{2}+\frac{R_{D 3}}{\left|V_{3}\right|^{2}\left(p f_{3}\right)^{2}}\left(P_{3}\right)^{2} \\
& P_{L}=\frac{0,002}{||^{2}(0,81)^{2}}\left(20^{2}\right)+\frac{0,003}{|0,99|^{2}(0,8)^{2}}(12)^{2}+\frac{0,001}{|0,98|^{2}(0,8)^{2}}(10)^{2}
\end{aligned}
$$




$$
\begin{aligned}
& P_{L}=1,2193+0,6886+0,16269 \\
& P_{L}=2,0703 \mathrm{MW}
\end{aligned}
$$

Sehingga besar beban jika rugi-rugi daya saluran diperhitungkan

$$
\begin{aligned}
& P_{D}=\sum_{i=1}^{n} P_{g i}-P_{L} \\
& P_{D}=42 M W-2,0703 M W \\
& P_{D}=39,9297 M W
\end{aligned}
$$

b. Besar rugi daya sistem transmisi

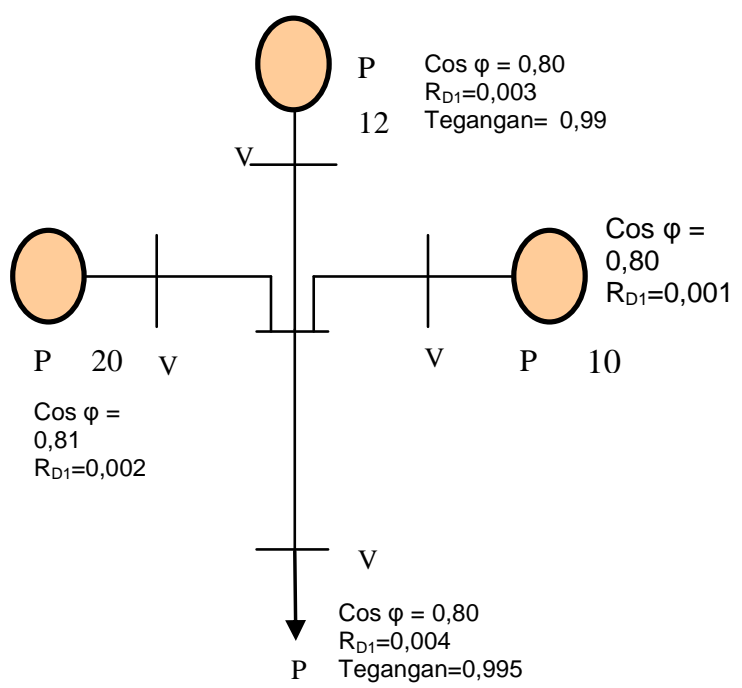

panjang

Gambar 9. Model jaringan perhitungan rugi rugi( Jaringan Panjang)

Masalah rugi daya pada saluran transmisi dijelaskan George, dalam "George's Formula" untuk suatu sistem pemasok daya dengan tiga sumber pembangkit dan satu pusat beban adalah

$$
P_{L}=\sum_{i=1}^{3} \sum_{j=1}^{3} P_{g i} B_{i j} P_{g}
$$

Atau dalam persamaan

$$
P_{L}=3\left(I_{1}^{2} R_{D 1}+I_{2}^{2} R_{D 2}+I_{3}^{2} R_{D 3}+I_{4}^{2} R_{D 4}\right)
$$

Dimana :

$$
\begin{aligned}
& \left|I_{1}\right|=\frac{P_{1}}{\sqrt{3}\left|V_{1}\right|\left(p f_{1}\right)} \\
& \left|I_{2}\right|=\frac{P_{2}}{\sqrt{3}\left|V_{2}\right|\left(p f_{2}\right)} \\
& \left|I_{3}\right|=\frac{P_{3}}{\sqrt{3}\left|V_{3}\right|\left(p f_{3}\right)}
\end{aligned}
$$

$$
\begin{aligned}
& \left|I_{4}\right|=\frac{P_{1}+P_{2}+P_{3}}{\sqrt{3}\left|V_{4}\right|\left(p f_{4}\right)} \\
& P_{L}=\frac{R_{D 1}}{\left|V_{1}\right|^{2}\left(p f_{1}\right)^{2}}\left(P_{1}^{2}\right)+\frac{R_{D 2}}{\left|V_{3}\right|^{2}\left(p f_{2}\right)^{2}}\left(P_{2}\right)^{2}+\frac{R_{D 3}}{\left|V_{3}\right|^{2}\left(p f_{3}\right)^{2}}\left(P_{3}\right)^{2}+\frac{R_{D 4}}{\left|V_{4}\right|^{2}\left(p f_{4}\right)^{2}}\left(P_{1}+P_{2}+P_{3}\right)^{2} \\
& P_{L}=\frac{0,002}{||^{2}(0,81)^{2}}\left(20^{2}\right)+\frac{0,003}{|0,99|^{2}(0,8)^{2}}(12)^{2}+\frac{0,001}{|0,98|^{2}(0,8)^{2}}(10)^{2}+\frac{0,004}{|0,995|^{2}(0,8)^{2}}(20+12+10)^{2} \\
& P_{L}=1,2193+0,6886+0,16269+4,4707 \\
& P_{L}=6,541 \mathrm{MW}
\end{aligned}
$$

Sehingga besarnya rugi-rugi daya pada saluran transmisi sebesar $=6,541 \mathrm{MW}$

\subsection{Kasus 2 .}

Suatu sistem tenaga listrik terinterkoneksi sengkang, PLTA Bakaru, PLT Tello, dan PLTD Suppa beroperasi full load pada jam 18.00 dan 19.00 beban puncak. Sengkang terjadi speed drop apabila beban naik dari pukul 18.00 sampai 19.00 sebesar $3 \%$, PLTA Bakaru $2 \%$, PLT Tello 4\% dan PLT Suppa $1 \%$. Data-data diasumsikan dari sulsel-bar.

Prediksikan beban pada pukul 18.00 dan pukul 19.00. Tentukanlah :
a. Daya yang dipikul masing-masing PLT pada saat pukul 18.00 (prediksi)
b. Tentukanlah perubahan frekuensi kalau diasumsikan pada beban pukul 18.00, $\mathrm{f}$ $=50 \mathrm{~Hz}$, Jika beban naik pada pukul 19.00
c. Tentukanlah besar daya yang harus disuplai PLT-PLT pada pukul 19.00


ISSN $1979-7540$

\section{Penyelesaian :}

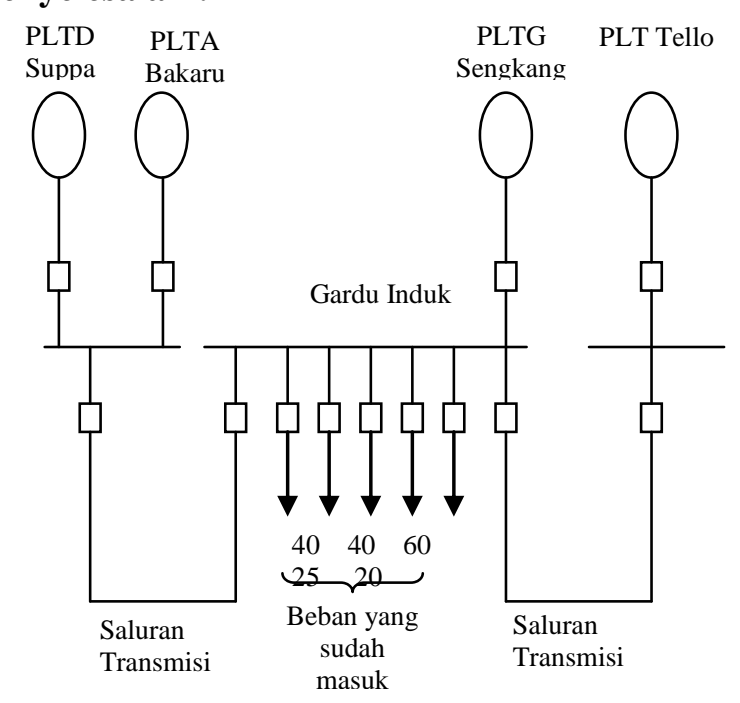

Gambar 10. Sebuah sistem interkoneksi terdiri dari 4 pembangkit

Data untuk daya masing-masing pembangkit sebagai berikut :

- PLTG Sengkang = 60 MW, speed drop

$$
=3 \%
$$

- PLTA Bakaru $=60 \mathrm{MW}$, speed drop $=2 \%$

- PLT Tello $=75 \mathrm{MW}$, speed drop $=$ $4 \%$

- PLTD Suppa $=30 \mathrm{MW}$, speed drop $=1 \%$

Keadaan system mula-mula seperti ditunjukkan pada gambar 18. yaitu jumlah beban $40+40+60+25=165 \mathrm{MW}$ dengan frekuensi $50 \mathrm{~Hz}$. Pada pukul 18.00 Diasumsikan bahwa dalam perhitungan ini rugi-rugi saluran transmisi diabaikan kemudian dilakukan penambahan beban sebesar 20 MW pada pukul 19.00

a. Prediksi daya yang dipikul masingmasing PLT pada saat pukul 18.00 yaitu :

- $\quad$ PLTG Sengkang $=50 \mathrm{MW}$

- PLTA Bakaru $=50 \mathrm{MW}$

- PLT Tello $=50 \mathrm{MW}$

- PLTD Suppa $\quad=15 \mathrm{MW}$

b. Jika pukul 18.00 keadaan sistem dengan jumlah beban sebesar 165 MW dengan frekuensi sistem $50 \mathrm{~Hz}$ dan pada pukul $\quad 19.00$ terjadi penambahan beban sebesar 20 MW maka terjadi penurunan frekuensi.

\section{- $\quad$ PLTG Sengkang}

Beban $=0 \mathrm{MW}$, frekuensi $=1,03 \times 50=$ $51,5 \mathrm{~Hz}$

Beban $=60 \mathrm{MW}$, frekuensi $=50 \mathrm{~Hz}$

$$
K f=\frac{0-60}{51,5-50}=-40 \mathrm{MW} / \mathrm{Hz}
$$

\section{- PLTA Bakaru}

Beban $=0 \mathrm{MW}$, frekuensi $=1,02 \times 50=51$

$\mathrm{Hz}$

Beban $=60 \mathrm{MW}$, frekuensi $=50 \mathrm{~Hz}$

$K f=\frac{0-60}{51-50}=-60 \mathrm{MW} / \mathrm{Hz}$

\section{- PLT Tello}

Beban $=0 \mathrm{MW}$, frekuensi $=1,04 \times 50=52$ $\mathrm{Hz}$

Beban $=75 \mathrm{MW}$, frekuensi $=50 \mathrm{~Hz}$

$K f=\frac{0-75}{52-50}=-37,5 \mathrm{MW} / \mathrm{Hz}$

\section{- PLTD Suppa}

Beban $=0 \mathrm{MW}$, frekuensi $=1,01 \times 50=$ $50,5 \mathrm{~Hz}$

Beban $=30 \mathrm{MW}$, frekuensi $=50 \mathrm{~Hz}$

$K f=\frac{0-30}{50,5-50}=-60 \mathrm{MW} / \mathrm{Hz}$

Maka besarnya Kf sistem $=-40-60-37,5$ $-60=-197,5 \mathrm{MW} / \mathrm{Hz}$.

Dengan penambahan beban sebesar 20 MW pada pukul 19.00 kedalam sistem akan terjadi perubahan nilai frekuensi sebesar :

$\Delta f=\frac{\Delta P}{K f}=\frac{20}{-197,5}=-0,101 \mathrm{~Hz}$

Setelah ada penambahan beban pada pukul 19.00 kedalam sistem sebesar 20 MW maka frekuensi sistem menjadi sebagai berikut :

Frekuensi sistem $=50 \mathrm{~Hz}-0,101 \mathrm{~Hz}=$ $49,89 \mathrm{~Hz}$

c. Besar daya yang harus disuplai masingmasing PLT pada pukul 19.00

\section{- PLTG Sengkang}

$\Delta P=K f . \Delta f=-40 x-0,101=4,04 M W$

PLTG Sengkang mensuplai daya menjadi $=50+4,04=54,04 \mathrm{MW}$

- PLTA Bakaru

$\Delta P=K f . \Delta f=-60 x-0,101=6,06 M W$

PLTA Bakaru mensuplai daya menjadi $=50+6,06=56,06 \mathrm{MW}$ 
- PLT Tello

$\Delta P=K f . \Delta f=-37,5 x-0,101=3,7875 M W$

PLT Tello mensuplai daya menjadi $=$ $50+3,7875=53,7875 \mathrm{MW}$

- PLTD Suppa

$\Delta P=K f . \Delta f=-60 x-0,101=6,06 M W$

PLTD Suppa mensuplai daya menjadi $=15+6,06=21,06 \mathrm{MW}$

\section{KESIMPULAN}

1. Untuk kasus 1 dengan 3 (tiga) pembangkit : PLTG Daya $20 \mathrm{MW}$, PLTU Daya 12 MW dan PLTD Daya 12 MW jika diasumsikan saluran transmisi pendek dengan rugi -rugi yang diperhitungkan diperoleh besar beban adalah 39,9297 MW sedangkan untuk rugi-rugi yang tidak diperhitungkan dan $42 \mathrm{MW}$.

2. Pada Kasus I besar rugi daya sistem jika transmisisnya adalah transmisi panjang diperoleh sebesar 6,541 MW.

3. Untuk kasus 2 dengan sistem yang saling interkoneksi antara PLTG sengkang, PLTA Bakaru, PLT Tello, dan PLTD Suppa beroperasi full load pada jam 18.00 dan 19.00 beban puncak, diperoleh prediksi daya yang dipikul masing-masing PLT pada pukul 18.00 sebesar $165 \mathrm{MW}$ (PLTG,PLTA dan PLT Tello masingmasing sebesar $50 \mathrm{MW}$ dan PLTD sebesar $15 \mathrm{MW})$. Selanjutnya pada pukul $\quad 19.00$ terjadi penambahan beban sebesar $20 \mathrm{MW}$ dimana terjadi penurunan frekuensi sistem sebesar 49,89 Hz dan Besar daya yang harus disuplai masing-masing PLT pada pukul 19.00 sebesar 184,9475 MW (PLTG Sengkang 54,04 MW, PLTA Bakaru 56,06 MW, PLT Tello 53,7875 MW dan PLTD Suppa 21,06 MW).

4. Setelah ada penambahan beban, frekuensi menurun dan governor beraksi untuk mengembalikan frekuensi ke nilai semula yaitu $\mathrm{F}$.

5. Speed Drop dari masing masing pembangkit jika terjadi perubahan beban akan berubah sesuai besar daya yang disupplai pembangkit tersebut. Pembangkit yang mempunyai speed drop kecil mensuplai tambahan daya beban yang lebih besar dari pada unit pembangkit yang mempunyai speed drop besar.

6. Pengaturan frekuensi dalam sistem berarti pula pengaturan kopel penggerak Generator atau juga berarti pengaturan daya aktif dari generator.

7. Ditinjau dari segi mesin penggerak generator ini berarti bahwa pengaturan frekuensi sistem adalah pengaturan pemberian bahan bakar pada unit termis dan pengaturan pemberian air pada unit PLTA, yang selanjutnya akan memberikan tambahan biaya

\section{DAFTAR PUSTAKA}

Djiteng Marsudi, Operasi Sistem Tenaga Listrik, Jogjakarta, Graha Ilmu, 2006.

Harun, Nadjamudin,. Perancangan Pembangkit Sistem Tenaga Listrik_Materi kuliah Tidak dipublikasikan. Universitas Hasanuddin . Makassar, 2008.

Hutauruk. Transmisi Tenaga Listrik. Jakarta, 1980.

Innah,Hebert, dkk. Incramental Loading analysis in critical buses using two port Network in $500 \mathrm{kV}$ Java System, Proceedings MICEEI, Unhas Makassar, November 2008

Mohamed E El Hawary, Electrical Power Systems Design and Analysis, New York, IEEE Press Power Systems Engineering Series, 1995.

Kitta,Ikhlas . Ansar Suyuti. Electrical Model simulation of the power Plant Technology on Games Theory method (Case study Bontang city electrical system of east kalimantan). Proceedings MICEEI Unhas, Makassar, 2008.

Kitta,Ikhlas . Salama Manjang. Penerapan Teori permainan dalam proses pemilihan Teknologi Pembangkit. Proceding SNKT Elektro Unhas, Makassar, 2007.

Saadat,Hadi. Power System Analysis. Mc Graw Hill, Singapure, 1999.

Wood, Jallen and Bruce F.Wollenberg, Power Generation, Operation and Control, John Wiley and Sons, New York, 1984. 